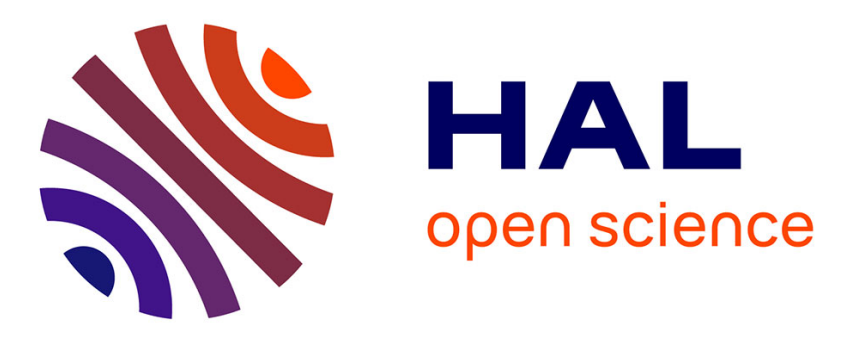

\title{
Quantifying genetic distance between wild and captive strains of the grey partridge Perdix perdix in France: conservation implications
}

Nicolas Bech, Claude Novoa, Jean-François Allienne, Jérôme Boissier, Elisabeth Bro

\section{To cite this version:}

Nicolas Bech, Claude Novoa, Jean-François Allienne, Jérôme Boissier, Elisabeth Bro. Quantifying genetic distance between wild and captive strains of the grey partridge Perdix perdix in France: conservation implications. Biodiversity and Conservation, 2019, 29 (2), pp.609-624. 10.1007/s10531019-01901-w . hal-02417150

\author{
HAL Id: hal-02417150 \\ https://hal.science/hal-02417150
}

Submitted on 12 Apr 2021

HAL is a multi-disciplinary open access archive for the deposit and dissemination of scientific research documents, whether they are published or not. The documents may come from teaching and research institutions in France or abroad, or from public or private research centers.
L'archive ouverte pluridisciplinaire HAL, est destinée au dépôt et à la diffusion de documents scientifiques de niveau recherche, publiés ou non, émanant des établissements d'enseignement et de recherche français ou étrangers, des laboratoires publics ou privés. 


\title{
Quantifying genetic distance between wild and captive strains of the grey partridge Perdix perdix in France: conservation implications
}

\author{
Nicolas Bech ${ }^{1}$ - Claude Novoa ${ }^{2}$ Jean-François Allienne ${ }^{3}$. \\ Jérôme Boissier ${ }^{3}$ Elisabeth Bro ${ }^{4}$
}

1 Laboratory of Ecologie et Biologie des Interactions (EBI), CNRS, UMR 7267, Poitiers University, 5 rue Albert Turpain, TSA 51106, 86073 Poitiers Cedex, France

2 National Game and Wildlife Agency, Research Department, 66500 Prades, France

Corresponding author nicolas.bech@univ-poitiers.fr

\begin{abstract}
The grey partridge Perdix perdix is an important gamebird in Europe. Its numbers have decreased dramatically during the XXth century and releases are commonly undertaken for the conservation of the populations and/or hunting purposes in Western Europe. However, this practice that generally involves birds from commercial farms raises several concerns, among which a potential hybridization between farmed and wild individuals. Herein, based on microsatellite markers, we characterize the genetic patterns of farmed birds in view of wild birds of the two French subspecies ( $P$. p. armoricana in centralnorthern France and P. p. hispaniensis in the Pyrenees). Hence, we estimate the risk of genetic introgression between wild and farmed birds. Our results highlight a genetic divergence between both subspecies - in accordance with the known evolutionary history of the grey partridge during the Quaternary. In central-northern France, a slight but significant difference in the genetic signature between wild and farmed partridges is detected. This difference however does not seem prone to alter the gene pool of wild birds if farmed birds are released in the wild and reproduce. On the contrary, in the Pyrenees, the large and significant genetic difference between wild and farmed birds represents a real risk of genetic introgression. This threat should be taken into account in population management.
\end{abstract}

\section{Keywords}

Perdix perdix - Conservation - Hybridization - Genetic introgression · 


\section{Introduction}

To face biodiversity erosion, release programs are commonly employed to reinforce the effective size and consequently the resilience of collapsing populations of threatened species (Armstrong et al. 2015; IUCN/SSC 2013). In such programs genetic considerations play a crucial role (Frankham et al. 2010). Indeed, genetic diversity represents the raw material for adaptive evolutionary changes, notably because its loss can lead to reduction in reproductive fitness, as it can be observed in populations suffering from inbreeding depression (Frankham et al. 2010). Even if inbreeding effects on wild populations are complex, there are now ample evidences that inbreeding depression can reduce population's viability via a decrease in survival and/or reproduction abilities of individuals (Frankham et al. 2010). Thus, releases of individuals carrying potentially new alleles are expected to increase population fitness by restoring adaptive variations and removing possible inbreeding effects. However, the use of individuals from non-local stocks might also cause losses of local genetic adaptations (i.e. genetic swamping), resulting from an outbreeding depression. In such case, hybrid descendants have a lower fitness than their parents (Randi 2007; Sutherland et al. 2006). This outbreeding depression can appear when genetic differences between the source and target populations are too important. Such differences can result from the combined effect of a genetic drift and the disappearance of specific adaptations that have occurred during the evolutionary process (Randi 2007). Insofar as possible, a compromise should be found between the maintenance of the genetic diversity, on the one hand, and the risk of outbreeding depression, on the other hand, in order to the genetic criteria may be prone to play a crucial role for the success of release programs. These considerations are now part of the risk assessment that should be considered before a release program is implemented (i.e. "gene escape", (IUCN/SSC 2013). Thus, the challenge lies in finding a "source population" sufficiently different to rehabilitate the genetic diversity of the target population, without being inconsistent and causing an outbreeding depression into the hybrid offspring. This compromise may be a special challenge when released individuals come from conservative breeding program centers or commercial farms. Indeed, captive stocks are generally founded with few individuals whose genetic pattern is not well characterised. In addition, whatever the origin of founders, inbreeding and genetic drift increase with successive generations and are likely to modify the genetic signature of captive stocks.

Such genetic effects have already been highlighted as potential concerns for the grey partridge (Blanc et al. 1986; Effenberger and Suchentrunk 1999). France supports almost $50 \%$ of the European stock of this species (BirdLife_International 2015). It mainly occurs in central northern plains (Bro and Crosnier 2012) and in the Pyrenees above $1000 \mathrm{~m}$ above sea level (OGM 
2011), respectively, as two biogeographical and genetic subspecies (Perdix $p$. armoricana and P. p. hispaniensis, Martin et al. 2003). Both subspecies experienced an important decline since World War II, that still goes on nowadays (BirdLife_International 2015; EBCC 2015; Reitz and Mayot 2017). This ongoing trend is both observed in intensively cultivated lowlands as well as in Pyrenean mountain tops due to an array of environmental causes among which the global climatic and habitat changes (Bro and Reitz 2014; Godin and Bro 2017; Novoa 1998; Reitz and Mayot 2017). As a consequence, both subspecies have been red listed as "Near threatened" in some French regions (CSRPN 2013; UICN-France et al. 2016). In turn, releases are commonly performed for conservation or hunting purposes, using birds from conservative breeding programs or commercial farms (Bro et al. 2016, 2017; SNPGC-Syndicat National des Producteurs de Gibier de Chasse 2019). This practice raises several concerns, among which a potential genetic introgression resulting from hybridizations between farmed and wild individuals, as already highlighted in the subspecies P. p. hispaniensis (Bech et al. 2012; Martin et al. 2003) and in P. p. lucida (Liukkonen 2006). However, this conservation concern may also be raised with the European western subspecies, the so-called $P$. p. armoricana since farmed birds may evolve in strains/lineages presenting some specific genetic profiles due to selection and some degree of drift/inbreeding (Blanc et al. 1986; Liukkonen 2006).

In this context, we examine herein the genetic structure of farmed grey partridges from a diversity of conservative breeding program centers and commercial farms and compare it to several French wild populations.

\section{Materials and methods}

\section{Sample}

We collected 753 wings of harvested wild birds from both subspecies of grey partridge: Perdix perdix hispaniensis occuring in the Pyrenees $(n=604$, from 1986 to 2008) and P. p. armoricana occurring in the Central northern France ( $n=149$, from 2007 to 2014). We geolocated each individual according to the coordinates of the municipality where the bird was hunted (longitude and latitude in the World Geodetic System 1984 (WGS 84)). Based on geographical distances, individuals from the Pyrenees were gathered into 17 groups for analyses conducted at the scale of the population, and those from Central northern France into 5 groups (Table 1; Fig. 1).

We also collected samples from 230 harvested farmed individuals released in the wild (ringed birds): 41 in the Pyrenees from three different farms, 189 in central northern France from nine different farms. Moreover, we also analysed individuals from two conservative breeding programs, one: in the 
Pyrenees [i.e. "Pallars Sobirà", 57 individuals (F1/F2)] and one in central northern France [11 individuals (F1)].

Hence, our total of 1051 individuals were gathered into 36 groups representing either a wild population, a farm or a conservative breeding program center (hereafter "groups"). This large and diversified sample allowed us to robustly picture the genetic signature of both wild and farmed individuals.

\section{Molecular markers}

We extracted DNA from all samples using silica columns (e.Z.N.A from OMEGA BIOTEK), according to the manufacturer protocol. Because mitochondrial markers have only a maternal inheritance and thus the signal of the genetic introgression is lost when wild females mate, we genotyped all samples using 12 nuclear molecular markers: microsatellites: MNT412, MNT12, MNT477, MNT404, MNT467, MNT408 (Bech et al. 2010), Aru1G4, Aru1F25 (Ferrero et al. 2007), ADL142, LEI31, LEI319 (Mautner 2001) and BG15 (Piertney and Höglund 2001). We amplified the relevant DNA fragments using the Polymerase Chain Reaction (PCR) and the QIAGEN multiplex kit. The PCR amplifications were carried out according to the manufacturer standard microsatellite amplification protocol in a final volume of $10 \mu \mathrm{L}$ and at $57^{\circ} \mathrm{C}$ for annealing temperature. Moreover, the PCR amplifications of loci MNT412, MNT12 and BG15 were grouped in the multiplex 1; loci MNT477, MNT404, ADL142, LEI31 and LEI319 were grouped in the multiplex 2; loci Aru1G4, Aru1F25 and MNT408 were grouped in the multiplex 3 and finally, the last microsatellite marker MNT467 was amplified alone. We added $1 \mu \mathrm{L}$ of PCR product to $9 \mu \mathrm{L}$ formamide and $0.5 \mu \mathrm{L} 600 \mathrm{LIZ}$ standard (Life Technologies) and visualized it by electrophoresis on an ABI PRISM 3130 Genetic analyser. We determined amplification product size using Genemapper software (Applied Biosystems), followed by visual verification.

We used the software Micro-Checker (Oosterhout et al. 2004) to identify the presence of null alleles or scoring errors due to stuttering. The level of significance was adjusted using a Bonferroni correction as implemented in the software.

Departures from Hardy-Weinberg expectations as well as linkage disequilibria were assessed using exact tests (1200 permutations) implemented in Fstat v.2.9.3.2. (Goudet 2001). The level of significance for multiple testing was adjusted using the Chandler correction because Bonferroni's procedure is considered too conservative when strictly applied. We used an error rate of $10 \%$ as suggested by Chandler (1995). 


\section{Analysis of the global genetic structure}

\section{Genetic diversity}

We estimated the polymorphism of each of the 36 groups of birds. For this purpose, we computed over all loci the allelic richness (AR), the expected heterozygosity (He) (Weir and Cockerham 1984) and the Fis using FSTAT v.2.9.3.2. We performed Anova tests for AR and He between each pairwise groups to detect potential differences in genetic variations.

\section{Genetic structure}

We examined the global genetic structure of the 1051 individuals using the Bayesian approach implemented in Structure v.2.0 (Pritchard et al. 2000). We chose the admixture model and the option of correlated allele frequencies among groups. This software assigns each individual to a given genetic cluster, the number of genetic clusters varied from 1 to 5 . Each simulation was replicated 20 times as recommended (Evanno et al. 2005), with 10000 burnin iterations followed by 500000 sample iterations.

The likely number of independent genetic clusters (K) was obtained using Structure Harvester software version 0.6.1 (Earl and vonHoldt 2012). It compares the likelihood of the dataset for the different values of $\mathrm{K}$. We also described the distribution of microsatellite variability using a Factorial Correspondence Analysis (FCA) based on the birds' genotypes. Finally, to estimate the genetic differentiation between all pairwise groups, we used the software Fstat v.2.9.3.2. to calculate Fst values according to Weir and Cockerham (1984). The level of significance of the tests was adjusted for multiple testing using the Chandler correction and an error rate of $10 \%$ (Chandler 1995).

\section{Genetic differences between wild and farmed individuals}

We selected 103 individuals assigned to the "wild" genetic cluster and 16 to the "farmed" one, using the proportions of ancestry inferred from the Bayesian approach implemented in Structure v.2.0 (i.e. qi-value $>0.97$ ).

The genotypes of these selected individuals were implemented as 'parent genotypes' in the software Hybridlab v1.0 (Nielsen et al. 2006) which simulates random mattings and supplies the genotypes of artificial hybrids. By this way we built 100 artificial F1 hybrids and 100 artificial F2 hybrids (i.e. F1 × F1).

The genetic signatures of these 200 artificial hybrids were pooled with the ones of the 1051 biological birds and implemented into the Newhybrids software (Anderson and Thompson 2002) to assign each "individual"to one of the four categories: each pure subspecies (i.e. "Pure_P.p.hispaniensis" and "Pure_P.p.armoricana") and hybrids (i.e. "F1 hybrids" and "F2 hybrids"). NewHybrids was run with 10000 burn-in iterations followed by 1000000 Markov chain Monte Carlo iterations. Analyses did not use prior allele 
frequency information but considered uniform prior distributions for $\theta$ and $p$ parameters (Anderson and Thompson 2002). This procedure allowed us (1) to test the reliability of our approach, i.e. by checking the inference of our 200 known artificial hybrids to the suitable hybrid category, and (2) to estimate the frequency of the four genotypic categories with true birds.

\section{Genetic structure of groups of wild Pyrenean birds}

We only report here the genetic structure of groups of wild grey partridges collected in the Pyrenees, as exactly the same work has already been published with wild birds from central northern France (Bech et al. 2014).

We tested the occurrence of isolation-by-distance (IBD) using a regression analysis of the genetic distance (Fst values of pairwise wild groups, see above) against the Euclidian distance (simple Mantel test implemented in GENALEX software, Peakall and Smouse 2006). Moreover, we used Structure software in the same conditions as previously in order to estimate the likely number of genetic clusters corresponding to our wild birds collected in the Pyrenees.

\section{Results}

\section{Validation of molecular markers}

33 of the 432 tests exhibited null alleles but they were randomly distributed across loci and groups. Only two groups revealed deviations from HardyWeinberg expectations ( $\mathrm{P}$-value threshold after Chandler correction: $\mathrm{P}=$ 0.0002) (Supplementary file 1 ). Moreover, no evidence of linkage disequilibrium was detected ( $\mathrm{P}$-value threshold after Chandler correction: $\mathrm{P}=$ 0.001). As deviations from Hardy-Weinberg and null alleles were inconsistent across loci, we retained all loci in the analyses.

\section{Global genetic structure}

All microsatellite markers were polymorphic within all groups. The allelic richness ranged from 1.767 to 6.379 and the genetic diversity ranged from 0.232 to 0.944 (Supplementary file 1). Genetic diversities were similar across all groups $(P=0.34$ for He and $P=0.11$ for $A R)$. Fis values revealed that two groups had a heterozygosity excess, and one a heterozygosity deficit ( $\mathrm{P}$-value threshold after Chandler correction: $\mathrm{P}=0.0002$ ).

\section{Number of genetic clusters of wild birds}

The highest posterior probability for the number of genetic clusters was given for $\mathrm{K}=2$, corresponding to the two subspecies. Indeed, individuals collected in wild populations in the Pyrenees revealed high proportions of ancestry into the genetic cluster 1 (mean \pm SD: $0.847 \pm 0.001$ ) while individuals collected in wild populations in central northern France revealed high proportions of ancestry into the genetic cluster 2 (mean \pm SD: $0.838 \pm 0.001$ ) (Fig. 2). This 
clear-cut genetic differentiation between both subspecies can be visualised in the FCA output (Fig. 3) and is quantified by a mean Fst value $=0.072$ (Table 2; Supplementary file 2).

\section{Genetic difference between farmed and wild birds}

Fst values comparing wild and farmed birds revealed a significant genetic differentiation, both in central northern France (mean Fst value $=0.026$ ) and in the Pyrenees (mean Fst value $=0.108$ ). The FCA depicts a distinct distribution between the centroids of the groups of wild Pyrenean birds and the groups of farmed birds, with farmed birds being located among centroids of the groups of wild birds sampled in central northern France (Fig. 3). This suggests that farmed birds released in the Pyrenees belong to the subspecies P. p. armoricana or to a close related subspecies.

\section{Detection and repartition of hybrids}

\section{In the Pyrenees}

We selected genotypes from 103 wild and 16 ringed released individuals to depict the wild and farmed genetic signatures and then to artificially generate hybrids. We had some difficulties to infer genotypes of artificially generated hybrids using Newhybrid software. Indeed, only 29 over 100 F1 hybrids and 12 over $100 \mathrm{~F} 2$ hybrids have been inferred to suitable predefined F1 and F2 genetic categories, respectively.

However, as far as wild birds are concerned, 504 birds over 604 were inferred into 1 of the 4 predefined genetic categories. Accurately, 472 birds were inferred into the "Pure_P. p. hispaniensis" category, 19 into the "Pure_P. p. armoricana" and 13 into a hybrid classes (i.e. 2 into F1 class and 11 to the F2 class). The 100 other birds showed ambiguous genotypes making inferences difficult.

39 over 41 farmed birds released in the Pyrenees were inferred into the "Pure_P. p. armoricana" category. Finally, among the 57 individuals collected from Pyrenean conservation breeding programs, 8, 9, 1 and 10 were inferred into the "Pure_P. p. hispaniensis", "Pure_P. p. armoricana", "F1" and "F2" categories, respectively. The other birds showed ambiguous genetic profiles making inferences difficult to any class.

\section{In central northern France}

We could not discriminate wild and farmed birds as the posterior probabilities inferred all of them to a same genetic cluster. In this way, we have not been able to infer hybrids within sampling localities. 


\section{Genetic structure in Pyrenean wild populations}

The mean Fst values indicated a significant genetic differentiation across the groups revealing a substructure in the Pyrenees (mean Fst: $0.040 \pm 0.024 ; \mathrm{P}<$ $0.0004)$. This was corroborated at the individual scale by a significant positive correlation between genetic and Euclidian distances $\left(r^{2}=0.0092 ; P=0.0001\right)$. This result indicates a strong isolation by geographical distance. At the individual scale, results from both Structure and Structure-Harvester software revealed some difficulties to converge toward a defined number of genetic clusters K (as Delta K value $<20$ ), suggesting a unique genetic cluster $(K=1)$ and so a unique genetic signature of wild grey partridge in the Pyrenees.

\section{Discussion}

\section{Two distinct genetic subspecies of grey partridges in France}

Although already highlighted with mitochondrial markers (Martin et al. 2003), we quantified the differences between $P$. p. hispaniensis and $P$. p. armoricana wild birds using our set of 12 nuclear microsatellite markers. We both deepened the genetic characterization of these two subspecies and calibrated the scale for the genetic distance between wild and farmed birds.

The results presented herein support a divergence between both subspecies, estimating a mean Fst of 0.072 . This significant genetic differentiation is explained by the evolutionary history of the grey partridge during the Quaternary. The species experienced changes in its geographic distribution in Europe during ice ages (Birkan and Jacob 1988). In France, these changes resulted in both subspecies, $P$. $p$. armoricana occurring in central northern France and $P$. $p$. hispaniensis occurring southward in the highmountain zones of the Pyrenees (i.e. the meridional refuge to survive to quaternary ice caps) (Liukkonen-Anttila et al. 2002).

\section{Genetic structure across subspecies populations}

Within each subspecies, the genetic differentiation between groups of birds revealed lower rates of differentiation than between both subspecies. However, the genetic structure of wild populations is twice stronger in the Pyrenees than in central northern France, with mean Fst values of 0.040 and 0.019 , respectively (Bech et al. 2014). This result is likely to emerge from habitat structure. Indeed, even if central northern France represents a landscape largely fragmented by human activities, the level of fragmentation of suitable habitat for the grey partridge is higher in the Pyrenees. Indeed, for species restricted to high-mountain zones, habitat is often referred as 'sky islands' illustrating patches of suitable habitat surrounded by inappropriate landscape (i.e. valley) (Haila 2002). Whatever its level, the habitat fragmentation combined with the intrinsic low dispersal abilities of grey partridge [maximum distance of 1.5-2 km, with few cases $>10 \mathrm{~km}$ as recorded 
by telemetry (Bro et al. 2016)] could explain the high isolation by the distance detected herein in the Pyrenees compared to what occurs in central northern France (Bech et al. 2014). Such a genetic structure is often found in Galliform populations, in mountain landscapes [capercaillie Tetrao urogallus (Segelbacher et al. 2003), rock ptarmigan Lagopus muta pyrenaica (Bech et al. 2009)] as well as in plains (greater sage grouse Centrocercus urophasianus (Oyler-Mccance et al. 2005)).

\section{Differences between wild and farmed partridges}

In central northern France, even if the genetic differentiation between farmed and wild partridges is statistically significant, it is quantitatively weak (i.e. mean Fst value $=0.026$ ) and of the same order of magnitude that the genetic differentiation observed in the field between wild populations (mean Fst value $=0.018$ ). So, farmed birds - such as randomly sampled in our study-are genetically closed to the native $P$. $p$. armoricana. Thus, their genetic background does not seem prone to alter significantly the gene pool of wild birds occurring in this area.

On the contrary, in the Pyrenees, the genetic difference between wild and farmed partridges is much larger. Farmed individuals released into the Pyrenean wild populations are likely to belong, or to be genetically very closed, to the subspecies P. p. armoricana. Thus, there is an important risk of genetic introgression if the farmed birds released in nature reproduce with wild individuals. This risk was already documented in previous studies based on mitochondrial data (Martin et al. 2003) and is supported herein by the admixed genetic profiles. Indeed, even if our methods have not accurately inferred these admixed genotypes to a predefined hybrid class, we suppose they likely represent hybrid individuals. Moreover, we have obtained similar results with hybrids generated in silico. This difficulty to infer admixed genotypes to a predefined hybrid class can originate from either a weak genetic resolution of our microsatellite marker panel or a low frequency of hybrids in populations. A low frequency may result from the combination of a low survival of partridges released on the field $<30 \%$ a few months after release, Bro et al. 2016), a lower reproductive success of the released partridges (Buner et al. 2011) - that could be due to a less effective antipredator behaviour (see Mayot et al. 2012) as also observed in the quail (Capdevila et al. 2016) - or from the rapid disappearance of the hybrid genetic signature as first back-crosses occur.

\section{Conservation issues}

The genetic difference we found in the Pyrenees between wild and farmed partridges has important consequences with regard to conservation actions of the emblematic $P$. p. hispaniensis. Indeed, due to the genetic specificity of this 
subspecies and the detection of introgression in wild populations (Bech et al. 2012), releases have been forbidden above $1000 \mathrm{~m}$ asl to avoid further hybridizations. Some conservation release programs use birds from conservative breeding centers (from Esterri d'Aneu). However, the genetic pattern of these birds is finally only slightly closer to the one of wild birds (mean Fst value $=0.096$ ), compared to farmed birds found in commercial farms in the Pyrenees (mean Fst value $=0.108$ ). So, it is better, but not the best yet. The great difficulty to breed wild-born partridges in captivity, even birds born in captivity from rescued clutches (Millot et al. 2012; Vannesson et al. 2017), may explain the low availability of partridges genetically suitable. The significant genetic differentiation across wild Pyrenean populations may also raise the question whether local strains should be considered or not.

On the contrary, farmed partridges found in commercial farms* that are released in central northern France display a genetic pattern close to the one of wild birds (considered as such from a genetic point of view, knowing that quite a lot of partridges were released in the past, Bro et al. 2016). This result might be explained by local origins of founders used in commercial farms (Birkan 1979; Blanc et al. 1987) and/or regular backcrosses of captive strains with wild birds if any. In this context, the plus-value of conservative breeding centers seems quite less crucial, the genetic risk arisen by conservation or hunting releases** may be considered as weak.

* we did not detected strains of partridges said from "eastern Europe" that display a distinct genetic signature (East vs. West clades, Liukkonen-Anttila et al. 2002).

** hunting releases may however have adverse demographic effects on wild populations if harvest quotas are not strictly managed (Bro and Mayot 2006; Mauvy et al. 1992).

\section{Acknowledgements}

We wish to warmly thank all the field technicians from the French National Game and Wildlife Agency (ONCFS) and from Hunter associations (FDC 14, 35, 41 and 60 ) as well as hunters who collected the samples. We also thank our colleagues from the Govern of Andorra and the Generalitat de Catalunya, and the conservative breeding center at the ONCFS. We are grateful to two anonymous referees that provided helpful comments to revise the manuscript.

\section{Funding}

This research was supported by the Convention ONCFS-University of Poitiers-University of Perpignan-CNRS no. 201412 6171. Funds issued from partners and from the 2015 to 2020 State-Region Planning Contracts (CPER), 
the European Regional Development Fund (FEDER), the partnership arrangements in ecology and the environment (DIPEE).

\section{Compliance with ethical standards}

Conflict of interest All authors declare that they have no conflict of interest.

Ethical approval This study was conducted in accordance with the principles and specific guidelines of the French current legislation for animal welfare and wildlife regulations. No animal was killed for the purpose of this study. All the biological samples were collected from dead animals, by taking the opportunity of hunting bags. 


\section{References}

Anderson E, Thompson E (2002) A model-based method for identifying species hybrids using multilocus genetic data. Genetics 160:1217-1229

Armstrong D, Hayward M, Moro D, Seddon P (2015) Advances in reintroduction biology of Australian and New Zealand Fauna. Csiro Publishing, Clayton, p 320. https ://doi.org/10.1071/97814 86303021

Bech N, Boissier J, Drovetski S, Novoa C (2009) Population genetic structure of rock ptarmigan in the 'sky islands' of French Pyrenees: implications for conservation. Anim Conserv 12:138-146. https://doi.org/10.1111/j.14691795.2008.00233.x

Bech N, Novoa C, Allienne JF, Boissier J (2010) Transferability of microsatellite markers among economically and ecologically important galliform birds. Genet Mol Res 9:1121-1129. https ://doi.org/10.4238/ vol9-2gmr7 60

Bech N, Novoa C, Bro E, Boissier J (2012) Conservation de la diversité génétique des populations naturelles de perdrix grise: la question des lâchers d'oiseaux d'élevage. Faune Sauvag 297:10-14. http://www.

oncfs .gouv.fr/IMG/file/oisea ux/galli forme s/plain e/FS297_bech_perdr ix_grise_diver site_genet ique.pdf

Bech N, Manel S, Bro E, Novoa C, Bijaoui-Georget B, Beltran-Bech S, Boissier J (2014) Genetic connectivity of the grey partridge in central northern France in a highly man dominated landscape. Conserv Genet 15:10011011. https ://doi.org/10.1007/s1059 2-014-0594-z

BirdLife_International (2015) European red list of birds. Perdix perdix (Grey Partridge). Office for official publications of the European Communities, Luxembourg. http://www.birdl ife.org/dataz one/userfi les/ file/Speci es/erlob /summa rypdf s/22678 911_perdi x_perdi x.pdf

Birkan M (1979) Perdrix grise et rouge de chasse et d'élevage. La maison rustique, Paris, $\mathrm{p} 126$

Birkan M, Jacob M (1988) La perdrix grise. Hatier, Paris, p 284

Blanc $P$, Ledème $P$, Blanc $C-P$ (1986) variation géographique de la diversité génétique chez la perdrix grise (Perdix perdix). Gibier Faune Sauvage 3:541. http://www.oncfs.gouv.fr/IMG/file/oiseaux/galliformes/ plaine/PG_publi/perdrix\%20grise\%20Blanc\%201986\%20\%20GFS\%203.pdf

Blanc $F$, Ledeme $P$, Blanc C (1987) Quelques résultats des travaux menés sur la variabilité génétique chez la perdrix grise. Bulletin Mensuel de I'O.N.C.:113. http://www.oncfs .gouv.fr/IMG/file/oisea ux/galli forme s/plain e/PG_publi /perdr ix\%20gri se\%20Bla nc\%20198 7\%20\%20BM\%200NC \%20113.pdf

Bro E, Crosnier A (2012) Grey partridge Perdix perdix in France in 2008: distribution abundance, population change. Bird Study 59:320-326. https ://doi.org/10.1080/00063 657.2012.67409 9 
Bro $E$, Mayot $P$ (2006) Opérations de reconstruction des populations de perdrix grises et de perdrix rouges en France. Bilan quantitatif et acquis techniques. Faune Sauvag 274:6-24. http://www.oncfs .gouv.fr/ IMG/file/oisea ux/galli forme s/plain e/FS274_bro_mayot.pdf

Bro $E$, Reitz $F$ (2014) Perdrix grise. Mauvais succès reproducteur à répétition: quelle est la part de responsabilité de la météo? Faune Sauvag 302:49-50. http://www.oncfs .gouv.fr/IMG/file/oisea ux/galli forme $s /$ pegas e/FS_302_Bro_resea u_perdrix_faisa n.pdf

Bro E, Gest D, Novoa C (2016) La Perdrix grise. Biologie, écologie, gestion et conservation. Biotope, Mèze, p 304. https ://leclu b-bioto pe.com/libra irie-natur alist e/910-sousc ripti on-la-perdr ix-grise

Bro E, Sautereau L, Bouteiller R et al (2017) Opérations de repeuplement et de renforcement de populations de faisan commun et de perdrix grise. Rôle des conservatoires de I'ONCFS et du collectif Perdrix. Faune Sauvag 317:53-57. http://www.oncfs .gouv.fr/IMG/file/publi catio ns/revue \%20fau ne\%20 sau vage/Faune -sauva ge-317-4T201 7-Somma ire.pdf

Buner F, Browne S, Aebischer NJ (2011) Experimental assessment of release methods for the re-establishment of a red-listedgalliform, the grey partridge (Perdix perdix). Biol Conserv 144:593-601. https ://doi.org/10.1016/j.bioco n.2010.10.017

Capdevila J, Puigcerver M, López S, Pérez-Masdeu E, García-Galea E, Rodríguez-Teijeiro JD (2016) The role of nest-site selection and cereal production in differential nest predation in Common Quail Coturnix Coturnix and Hybrid Quail C. Coturnix $\times$ C. Japonica. Ibis 158(4):784-795. https ://doi. org/10.1111/ibi.12390

Chandler R (1995) Practical considerations in the use of simultaneous inference for multiple tests. Anim Behav 49:524-527. https ://doi.org/10.1006/anbe.1995.0069

CSRPN (2013) Liste rouge des oiseaux nicheurs de la région Centre.5p, http://www.centr e.devel oppem ent-durab le.gouv.fr/IMG/pdf/6-oisea ux-niche urs_2013_cle04 7818.pdf

Earl DA, vonHoldt BM (2012) STRU CTU RE HARVESTER: a website and program for visualizing STRU CTU RE output and implementing the Evanno method. Conserv Genet Resour 4:359-361. https ://doi.org/10.1007/s1268 6-0119548-7

EBCC (2015) European Bird Census Council. European wild bird indicators http://www.ebcc.info/index .php?ID=588

Effenberger S, Suchentrunk F (1999) Population genetics of grey partridge (Perdix perdix) in Austriapreliminary results. Hung Small Game Bull 5:179181

Evanno G, Regnaut S, Goudet J (2005) Detecting the number of clusters of individuals using the software STRUC TU RE: a simulation study. Mol Ecol 14:2611-2620. https ://doi.org/10.1111/j.1365294X.2005.02553 .x 
Ferrero ME, Gonzàles-Jara P, Blanco-Aguiar JA, Sànchez-Barbudo I, Dàvila JA (2007) Sixteen new polymorphic microsatellite markers isolated for redlegged partridge (Alectoris rufa) and related species. Mol Ecol Notes 7:1349-1351. https ://doi.org/10.1111/j.1471-8286.2007.01877 .x

Frankham R, Ballou J, Briscoe D (2010) Introduction to conservation genetics, 2nd edn. Cambridge University Press, Cambridge. https ://doi.org/10.1515/MAMM.2007.038

Godin S, Bro E (2017) Perdrix grise: analyse des conséquences des mauvaises reproductions à répétition sur les populations. Faune Sauvage 317:37-42. http://www.oncfs .gouv.fr/IMG/file/publi catio ns/revue \%20fau ne\%20sau vage/Faune -sauva ge-317-4T201 7-Somma ire.pdf

Goudet J (2001) FSTAT, a program to estimate and test gene diversities and fixation indices (version 2.9.3). http://www2.unil.ch/popge $\mathrm{n} / \mathrm{softw}$ ares/fstat .html

Haila Y (2002) A conceptual genealogy of fragmentation research: from island biogeography to landscape ecology. Ecol Appl 12:321-334. https ://doi.org/10.1890/1051-0761(2002)012\%5b032 1:acg of r\%5d2.0.co;2

IUCN/SSC (2013) Guidelines for Reintroductions and Other Conservation Translocations. Version 1.0. Gland, Switzerland: IUCN Species Survival Commission viiii, p 57. https ://porta Is.iucn.org/libra ry/sites/libra ry/files /docum ents/2013-2009.pdf

Liukkonen T (2006) Finnish native grey partridge (Perdix perdix) population differs clearly in mitochondrial DNA from the farm stock used for releases. Ann Zool Fenn 43:271-279. https ://www.jstor .org/stabl e/23736 873

Liukkonen-Anttila T, Uimaniemi L, Orell M, Lumme J (2002) Mitochondrial DNA variation and the phylogeography of the grey partridge (Perdix perdix) in Europe: from Pleistocene history to present day populations. J Evol Biol 15:971-982. https ://doi.org/10.1046/j.1420-9101.2002.00460 .x

Martin JF, Novoa C, Blanc-Manel S, Taberlet P (2003) Les populations de perdrix grise des Pyrénées (Perdix perdix hispaniensis) ont-elles subi une introgression génétique à partir d'individus d'élevage? Analyse du polymorphisme de I'ADN mitochondrial. Les Actes du Bureau des Ressources Génétiques 4:115-126

Mautner S (2001) Genetic variability, inbreeding risk and fertility in the grey partridge (Perdix Perdix). PhD thesis Vienna university

Mauvy B, Lartiges A, Valery $M$, Péroux $R$ (1992) Chasse à la perdrix: comparaison de la vitesse de réalisation du prélèvement entre oiseaux issus d'élevage et oiseaux naturels. Bulletin Mensuel Office

National de la Chasse 171:7-11. http://www.oncfs .gouv.fr/IMG/file/oisea ux/galli forme s/plain e/ PG_publi /perdr ix\%20gri se\%20Mau vy\%20199 2\%20-\%20BM\%200NC \%20171 .pdf

Mayot P, Sautereau L, Baron V, Molins C, Gavard-Gongallud N, Bro E (2012) Repeupler avec des perdreaux gris de souche sauvage nés et élevés en captivité serait-il plus efficace? Faune Sauvage 297:4-9 
Millot $F$, Vannesson R, Thémée A, Audibert T, Mayot $P$, Bro E (2012) Survie et reproduction de perdrix grises sauvages en captivité. Bilan de trois années à l'élevage conservatoire de I'ONCFS. Faune Sauvage 296:10-14. http://www.oncfs .gouv.fr/IMG/pdf/FS296_perdr ix_sauva ges_capti vite.pdf

Nielsen EE, Bach LA, Kotlicki P (2006) HYBRIDLAB (version 1.0): a program for generating simulated hybrids from population samples. Mol Ecol Notes 6:971-973. https ://doi.org/10.111 1/j.1471-8286.2006.01433 .x

Novoa C (1998) La perdrix grise dans les Pyrénées-orientales. Utilisation de I'habitat, élément de démographie, incidence des brûlages dirigés. PhD thesis Université de Paris 6, p 200

OGM (2011) Evolution de la répartition communale du petit gibier en montagne de France. Décennie 2000- 2009. Faune Sauvage 290:1-16. http://www.oncfs .gouv.fr/IMG/file/oisea ux/galli forme s/monta gne/ FS290_enque te_petit_gibie r_monta gne.pdf

Oosterhout CV, Hutchinson WF, Wills DPM, Shipley P (2004) Micro-checker: software for identifying and correcting genotyping errors in microsatellite data. Mol Ecol 4:535-538. https ://doi.org/10.111 1/j.14718286.2004.00684.x

Oyler-Mccance SJ, Taylor SE, Quinn TW (2005) A multilocus population genetic survey of the greater sagegrouse across their range. Mol Ecol 14:12931310. https ://doi.org/10.1111/j.1365-294X.2005.02491 .x

Peakall R, Smouse PE (2006) GENALEX 6: genetic analysis in Excel. Population genetic software for teaching and research. Mol Ecol Notes 6:288-295. https ://doi.org/10.1111/j.1471-8286.2005.01155.x

Piertney SB, Höglund J (2001) Polymorphic microsatellite DNA markers in black grouse (Tetrao tetrix). Mol Ecol 1:303-304. https ://doi.org/10.1046/j.1471-8278.2001.00118.x

Pritchard JK, Stephens M, Donnelly P (2000) Inference of population structure using multilocus genotype data. Genetics 155:945-959 (PMID: 10835412) Randi E (2007) detecting hybridization between wild species and their domesticated relatives. Mol Ecol 17:285-293. https ://doi.org/10.1111/j.1365-294X.2007.03417.x

Reitz F, Mayot P (2017) Situation et tendance d'évolution des populations de perdrix et de faisan commun vues à travers le réseau Perdrix-Faisan ONCFS-FNC-FDC. Faune Sauvage 317:4-9.

http://www.oncfs.gouv.fr/IMG/file/publi catio ns/revue \%20fau ne\%20sau vage/Faune -sauva ge-317-4T201 7-Sommaire.pdf

Segelbacher G, Höglund J, Storch I (2003) From connectivity to isolation; genetic consequences of population fragmentation in capercailie accross Europe. Mol Ecol 12:1773-1780. https ://doi.org/10.1046/ j.1365294X.2003.01873.x 
SNPGC-Syndicat National des Producteurs de Gibier de Chasse (2019) Productions de gibier. http://www. snpgc .fr/commu nique s_press e.php connexion 4th January 2019

Sutherland WJ et al (2006) The identification of 100 ecological questions of high policy relevance in the UK. J Appl Ecol 43:617-627. https ://doi.org/10.1111/j.1365-2664.2006.01188.x

UICN-France, MNHN, LPO, SEOF, ONCFS (2016) La Liste rouge des espèces menacées en France - Chapitre Oiseaux de France métropolitaine. Paris, France, $p$ 31. https ://inpn.mnhn.fr/docs/LR_FCE/ UICN-LR-Oisea ux-diffu sion.pdf

Vannesson R, Audibert T, Deshayes K, Bro E (2017) Comment améliorer la productivité des perdrix grises sauvages en captivité? Résultats d'un test mené à l'élevage conservatoire de l'ONCFS. Faune Sauvage 317:58-61. http://www.oncfs .gouv.fr/IMG/file/publi catio ns/revue \%20fau ne\%20sau vage/Faune -sauva ge-317-4T201 7-Somma ire.pdf

Weir BS, Cockerham CC (1984) Estimating F-statistics for the analysis of population structure. Evolution 38:1358-1370. https ://doi.org/10.1111/j.1558-5646.1984.tb056 57.x 
Table 1 List of the 36 groups of individuals ( $N=$ effective size) of grey partridges in the Pyrenees and Central northern France

\begin{tabular}{|c|c|c|c|c|c|c|}
\hline & \multicolumn{2}{|l|}{ Groups of individuals } & \multirow{2}{*}{$\frac{\mathrm{N}}{21}$} & \multirow{2}{*}{$\begin{array}{l}\mathrm{He} \\
0.64\end{array}$} & \multirow{2}{*}{$\begin{array}{l}\mathrm{Ar} \\
3.34\end{array}$} & \multirow{2}{*}{$\begin{array}{c}\text { Fis } \\
0.01\end{array}$} \\
\hline \multirow[t]{37}{*}{ Pyrenees } & Wild $(n=604)$ & 1 & & & & \\
\hline & P.p. hispaniensis & Canigo & 51 & 4 & 0 & 9 \\
\hline & & u 2 & & 0.64 & 3.32 & 0.05 \\
\hline & & Puigma & & 1 & 1 & 8 \\
\hline & & I & & & & \\
\hline & & 3 Carlit & 203 & 0.67 & 3.55 & 0.05 \\
\hline & & & & 9 & 6 & 2 \\
\hline & & 4 Cerdagne & 46 & 0.68 & 3.60 & 0.11 \\
\hline & & & & 3 & 1 & 0 \\
\hline & & 5 Andorre & 22 & 0.68 & 3.54 & 0.06 \\
\hline & & & & 2 & 0 & 0 \\
\hline & & 6 Madres & 16 & 0.61 & 3.15 & 0.01 \\
\hline & & & & 8 & 5 & 6 \\
\hline & & 7 Donezan & 12 & 0.63 & 3.31 & 0.05 \\
\hline & & & & 8 & 2 & 2 \\
\hline & & 8 Mont Tabe & 30 & 0.67 & 3.47 & - \\
\hline & & & & 5 & 5 & 0.014 \\
\hline & & 9 Aston & 32 & 0.66 & 3.39 & 0.09 \\
\hline & & & & 5 & 9 & 3 \\
\hline & & 103 & 11 & 0.67 & 3.47 & 0.02 \\
\hline & & Seigneurs & & 0 & 0 & 1 \\
\hline & & 11 Ustou & 24 & 0.62 & 3.32 & 0.09 \\
\hline & & & & 0 & 3 & 6 \\
\hline & & 12 & 41 & 0.64 & 3.48 & 0.07 \\
\hline & & MellesLuchon & & 9 & 4 & 0 \\
\hline & & 13 Vallée du & 36 & 0.64 & 3.33 & 0.11 \\
\hline & & Gave & & 2 & 7 & 3 \\
\hline & & 14 Aubisque & 19 & 0.66 & 3.61 & 0.10 \\
\hline & & & & 9 & 6 & 6 \\
\hline & & 15 Lescun & 7 & 0.60 & 3.10 & - \\
\hline & & & & 4 & 2 & 0.084 \\
\hline & & 16 Pallars & 25 & 0.64 & 3.43 & 0.02 \\
\hline & & Sobirà & & 6 & 1 & 9 \\
\hline & & 17 & 8 & 0.60 & 3.14 & 0.11 \\
\hline & & AltaRibagorça & & 1 & 0 & 6 \\
\hline & Conservative breeding & Pallars Sobirà & 57 & 0.67 & 3.52 & - \\
\hline & program & & & 2 & 9 & 0.007 \\
\hline
\end{tabular}


Farmed individuals $(\mathrm{n}=$ Andorre 41)

$\begin{array}{cll}\text { Central } & \text { Wild }(\mathrm{n}= & \text { BP1-sau } \\ \text { norther } & \text { 149) P. } p . & \text { BP2-sau } \\ \text { n France } & \text { armorican } & \text { BP3-sau } \\ & a & \end{array}$

Conservative breeding BP-cons program

Farmed individuals $(\mathrm{n}=$ BP-El1 189)

\begin{tabular}{|c|c|c|c|c|}
\hline \multirow[t]{2}{*}{ BP-El3 } & 24 & 0.69 & 3.74 & 0.08 \\
\hline & & 0 & 5 & 0 \\
\hline \multirow[t]{2}{*}{ BP-El4 } & 11 & 0.63 & 3.24 & - \\
\hline & & 0 & 0 & 0.106 \\
\hline \multirow[t]{2}{*}{ BP-EI6 } & 30 & 0.67 & 3.55 & 0.01 \\
\hline & & 7 & 1 & 5 \\
\hline \multirow[t]{2}{*}{ BP-El7 } & 29 & 0.65 & 3.39 & 0.01 \\
\hline & & 6 & 7 & 9 \\
\hline \multirow[t]{2}{*}{ BP-El8 } & 27 & 0.68 & 3.60 & 0.03 \\
\hline & & 3 & 7 & 7 \\
\hline \multirow[t]{2}{*}{ BP-El9 } & 26 & 0.66 & 3.44 & - \\
\hline & & 1 & 0 & 0.056 \\
\hline \multirow[t]{2}{*}{ BP-El11 } & 10 & 0.66 & 3.56 & - \\
\hline & & 3 & 9 & 0.031 \\
\hline \multirow[t]{2}{*}{ BP-El13 } & 12 & 0.67 & 3.50 & 0.04 \\
\hline & & 3 & 9 & 0 \\
\hline \multirow[t]{2}{*}{ Total } & 105 & & & \\
\hline & 1 & & & \\
\hline
\end{tabular}

Genetic indices for sampling localities: the allelic richness (AR), the expected heterozygosity ( $\mathrm{He}$ ) and Fis values. In italic: the Fis values significantly different from 0 ( $p$-value threshold after Chandler correction $p=0.0002$ )
$\begin{array}{llll}14 & 0.63 & 3.31 & -\end{array}$ $\begin{array}{lll}4 & 1 & 0.032\end{array}$
$110.58 \quad 2959-$ 3 0.099
$\begin{array}{llll}16 & 0.62 & 3.17 & 0.05\end{array}$ $\begin{array}{lll}0 & 8 & 2\end{array}$

$\begin{array}{llll}39 & 0.66 & 3.45 & 0.07\end{array}$

$\begin{array}{llll}52 & 5 & 2 & 6\end{array}$

$\begin{array}{llll}18 & 0.67 & 3.49 & 0.02\end{array}$ $\begin{array}{lll}1 & 4 & 7\end{array}$

$\begin{array}{lll}0.71 & 3.81 & 0.04\end{array}$ $\begin{array}{lll}1 & 0 & 6\end{array}$

$\begin{array}{llll}8 & 0.62 & 3.33 & 0.11\end{array}$ $\begin{array}{lll}1 & 9 & 4\end{array}$

$\begin{array}{llll}32 & 0.66 & 3.44 & -\end{array}$ $\begin{array}{lll}9 & 4 & 0.021\end{array}$

$\begin{array}{llll}11 & 0.66 & 3.51 & 0.13\end{array}$ $\begin{array}{lll}9 & 4 & 6\end{array}$

$\begin{array}{llll}20 & 0.65 & 3.42 & 0.08\end{array}$

$\begin{array}{lll}7 & 6 & 1\end{array}$




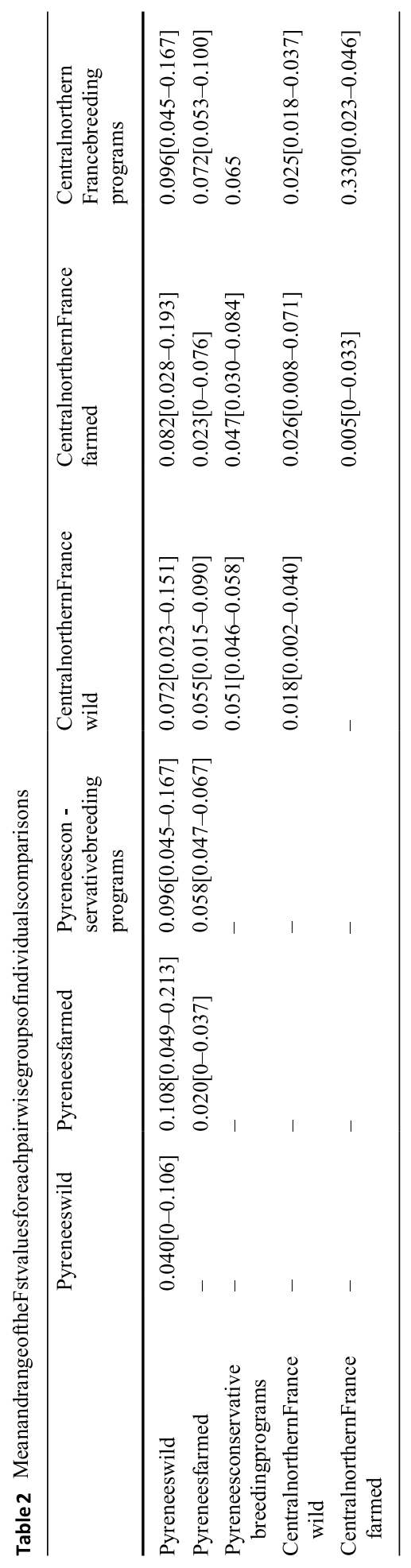




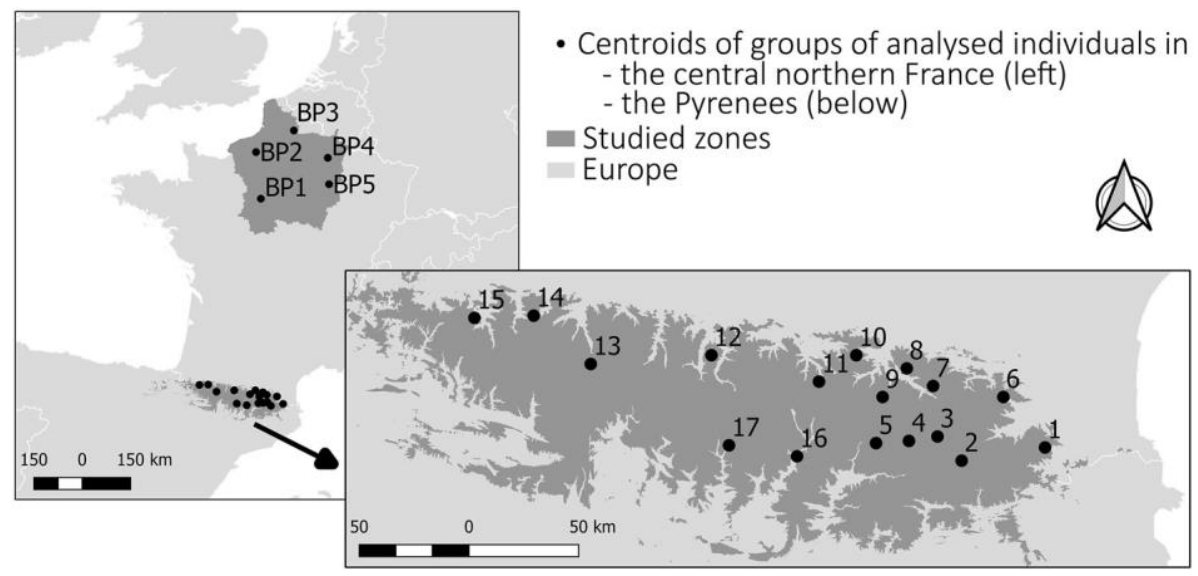

Figure 1

Maps of the studied zones (i.e. central northern France and Pyrenees) 


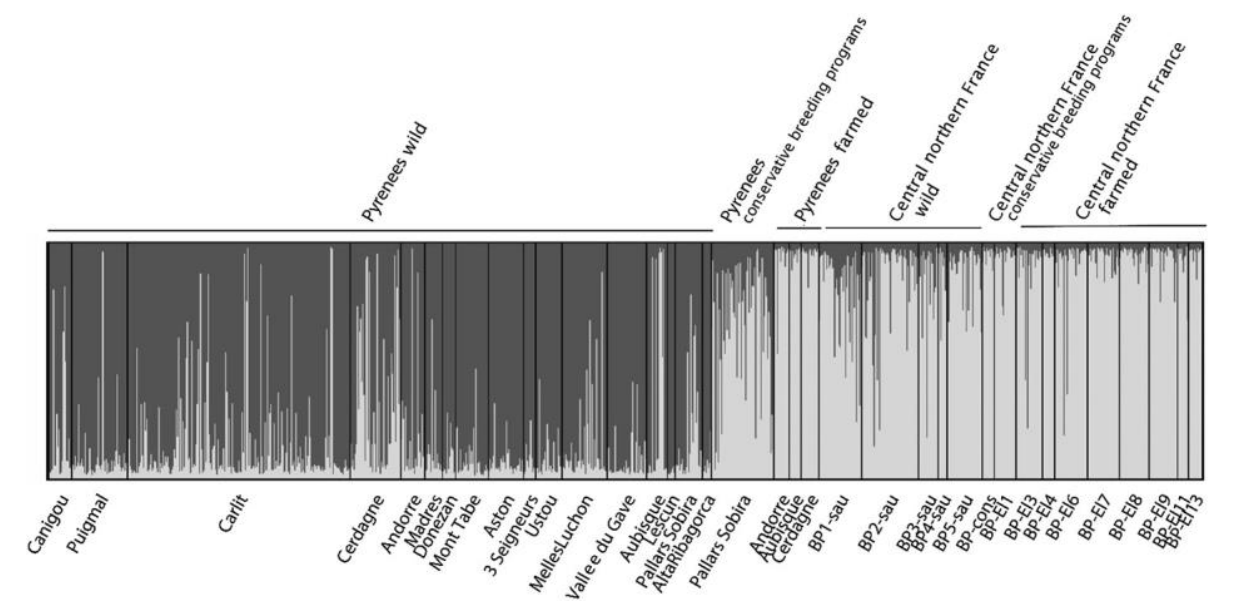

\section{Figure 2}

Results from Structure software: proportions of ancestry of each individual to the two inferred genetic clusters. Each individual is represented by a vertical bar, each color represents a genetic cluster and black lines separate the individuals from different groups 


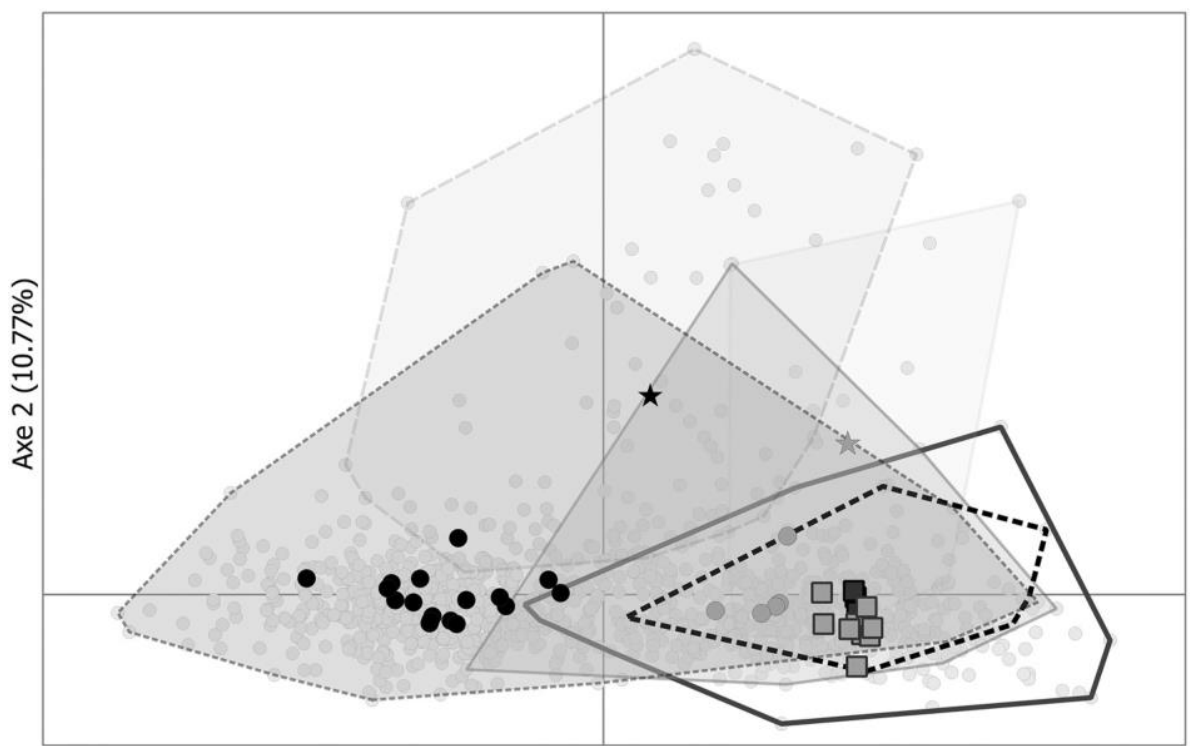

Axe $1(23.88 \%)$

\section{Legend}

Individuals $(n=1051)$

\section{Centroids of Individuals}

- Central northern France Wild (5 groups; $n=149$ )

- From the field (Pyrenees) (17groups; $n=604$ )

$\star$ From conservative breeding programs in Central northern France $(n=11)$

$\star$ From conservative breeding programs in Pyrenees $(n=57)$

$\square$ Farmed Central northern France ( 9 farms; $n=189$ )

口 Farmed Pyrenees (3 farms; $n=41$ )

\section{Polygons showing the individuals distribution from}

Wild from Central northern France

Wild from Pyrenees

From conservative breeding programs in Central northern France

From conservative breeding programs in Pyrenees

Farmed Central northern France

Farmed Pyrenees

\section{Figure 3}

Results of Factorial Correspondence Analysis (FCA) based on individuals' genotypes. This FCA was conducted on all individuals from both central northern France as well as Pyrenees and using Genetix software v.4.05.2. While individuals were characterised by light grey circles, we represented here groups' centroids in order to facilitate interpretations 